\title{
DEMAND VS SUPPLY PROGRAM KESEHATAN REMAJA DI PUSKESMAS TANAH KALIKEDINDING SURABAYA
}

\author{
DEMAND VS SUPPLY ADOLESCENT HEALTH PROGRAM IN PUSKESMAS \\ TANAH KALIKEDINDING SURABAYA
}

\author{
Kinanty Putri Sarweni, Rachmat Hargono \\ Departemen Promosi Kesehatan dan Ilmu Perilaku, \\ Fakultas Kesehatan Masyarakat, Universitas Airlangga, Surabaya. \\ Email: nankisarweni@gmail.com
}

\begin{abstract}
Adolescence is a period of transition from children to adulthood. In the transitional period, adolescents often face very complex and difficult issues to tackle on their own. Since 2003, Ministry of Health (Kementerian Kesehatan) has developed a model of health services that is competing with Health Care service for Youth (PKPR). Puskesmas Tanah Kalikedinding has promotive and preventive activities especially related to adolescents. PKPR is certainly based on every need and demand of teenage cadres around Tanah Kalikedinding area. The purpose of this study is to identify the needs and expectations of adolescent cadres on youth health programs. This research past descriptive research using qualitative approach. The research subjects consist of peer educator of Rumah Remaja, one of innovative program of Puskesmas Tanah Kalikedinding which refer to adolescent reproductive health, Adolescent Posyandu cadres, adolescent cadres in Al-Fitroh Pesantren and UKS cadres at SMAN 19 Surabaya. The number of informants used in this study are 6 persons. Data collection was obtained directly from the study sites using in-depth interview techniques and focus group discussions (FGDs) conducted by researchers with related adolescent peer. The results showed that adolescents need activities that always provide innovation, activities are not only curative but more on activities that are promotive and preventive such as counseling teenage health, education, and socialization.
\end{abstract}

Keywords: adolescent, program, health, need, expectation

\begin{abstract}
Abstrak: Masa remaja merupakan masa peralihan atau transisi dari anak-anak ke masa dewasa. Pada masa transisi, remaja sering menghadapi permasalahan yang sangat kompleks dan sulit ditanggulangi sendiri. Sejak tahun 2003, Kementerian Kesehatan telah mengembangkan model pelayanan kesehatan yang disebut dengan Pelayanan Kesehatan Peduli Remaja (PKPR). Puskesmas Tanah Kalikedinding telah memiliki kegiatan yang bersifat promotif dan preventif khususnya berkaitan dengan remaja. Kegiatan PKPR tentu didasarkan pada setiap kebutuhan dan keinginan dari remaja di sekitar wilayah Tanah Kalikedinding. Tujuan dari penelitian ini adalah mengidentifikasi kebutuhan dan harapan kader remaja terhadap program kesehatan remaja. Penelitian ini merupakan penelitian deskriptif dengan menggunakan pendekatan kualitatif. Subjek penelitian terdiri dari peer educator Rumah Remaja, yaitu salah satu program inovasi Puskesmas Tanah Kalikedinding yang merujuk pada kesehatan reproduksi remaja, kader Posyandu Remaja, kader remaja di Pondok Pesantren Al-Fitroh dan kader UKS di SMAN 19 Surabaya. Jumlah informan yang digunakan pada penelitian ini ialah 6 orang kader remaja. Pengumpulan data diperoleh langsung dari lokasi penelitian dengan menggunakan teknik wawancara mendalam dan focus group discussion (FGD) yang dilakukan oleh peneliti dengan kader remaja terkait. Hasil penelitian menunjukkan bahwa remaja membutuhkan kegiatan yang selalu memberikan inovasi, kegiatan tidak hanya bersifat kuratif namun lebih pada kegiatan yang bersifat promotive dan preventif seperti penyuluhan kesehatan remaja, edukasi, dan sosialisasi.
\end{abstract}

Kata kunci: remaja, program, kesehatan, kebutuhan, ekspektasi

\section{PENDAHULUAN}

WHO mengemukakan bahwa remaja merupakan kelompok manusia yang memiliki usia 10-19 tahun dan belum menikah (Depkes RI, 2003). Riskesdas
2007 menyebutkan bahwa di Indonesia usia remaja sangat besar jumlahnya dimana persentase menunjukkan angka $27 \%$ dari jumlah seluruh penduduk Indonesia. Menurut sensus penduduk Indonesia tahun 2010, menunjukkan bahwa kelompok usia 
tersebut sebesar 30 persen dari populasi penduduk di Indonesia. Penduduk remaja jumlahnya meningkat dari 35 juta pada tahun 1980 menjadi lebih dari 42,4 juta tahun 2010 (BPS 2010).

Masa peralihan atau transisi dari usia anak-anak menuju dewasa merupakan masa remaja. Remaja sering menghadapi permasalahan yang kompleks dan sulit pada masa transisi. Adapun tiga risiko yang sering dihadapi oleh remaja erat kaitannya dengan seksualitas dan dikelompokkan ke dalam TRIAD KRR, yaitu kehamilan yang tidak diinginkan, aborsi, dan terinfeksi penyakit menular seksual, penyalahgunaan NAPZA serta HIV AIDS (BKKBN 2012).

Sementara itu, dari hasil beberapa survey dari Kementerian Republik Indonesia pada riset tahun 2014 dapat diketahui bahwa pengetahuan remaja tentang kesehatan reproduksi masih rendah. Remaja dihadapkan dengan masa sulit dalam perkembangan baik secara mental, sosial, dan kultural. Hal tersebut dapat dilihat dari ketidakselarasan, gangguan emosi dan gangguan perilaku sebagai akibat dari tekanan yang dialami oleh remaja. Adanya ketidakselarasan dikarenakan perubahanperubahan yang terjadi pada dirinya maupun akibat perubahan lingkungan dan kehidupan social serta keluarga yang jarang mendukung remaja tumbuh dan berkembang.

Remaja juga terbatas aksesnya untuk mendapatkan pelayanan dan informasi yang benar. Hal ini disebabkan karena faktor lingkungan yang menyebabkan perilaku berisiko pada remaja yang dapat mengancam kemampuan remaja sebagai mata regenerasi untuk eksistensi makhluk hidup manusia. Salah satunya ialah informasi yang merugikan yang mudah diakses, hal ini terjadi seiring dengan pesatnya arus informasi melalui berbagai media cetak dan elektronik. Meskipun banyak informasi yang bersifat positif, namun sering kali informasi yang diberikan tidak dapat dipertanggungjawabkan misalnya karena kurang lengkap, tidak tepat, tidak benar dan menjerumuskan. Faktor lain dari kurangnya akses remaja terhadap informasi tentang kesehatan reproduksi adalah hambatan sosial dan kultural. Senderaowitz (1999) menyatakan bahwa remaja cenderung tidak menggunakan pelayanan kesehatan reproduksi yang ada dengan alasan ketakutan akan tidak terjamin kerahasiaannya dan khawatir akan dipersalahkan oleh petugas kesehatan.

Penanganan permasalahan remaja di Indonesia telah diupayakan walau masih banyak kekurangannya. Strategi untuk melaksanakan kebijakan kesehatan remaja dilakukan oleh pemerintah melalui kerja sama lintas sektoral, pelayanan kesehatan dasar dan rujukannya, dan pola intervensi. Strategi ini tentu telah disesuaikan dengan kebutuhan tahapan proses tumbuh kembang remaja (Depkes RI, 2003).

Data kunjungan di Puskesmas Tanah Kalikedinding Surabaya menunjukkan bahwa hingga bulan Juni 2016 remaja dengan usia 15-19 tahun lebih sering berkunjung ke pusat pelayanan kesehatan tersebut dibandingkan dengan kategori usia yang lain. Jumlah remaja perempuan yang berkunjung sebanyak 110 remaja sedangkan laki-laki 120 remaja yang berkunjung ke Puskesmas Tanah Kalikedinding Surabaya (Data Remaja Puskesmas Tanah Kalikedinding, 2016).

Pelayanan kesehatan yang diberikan di Puskesmas Tanah Kalikedinding menunjukkan bahwa angka pada remaja perempuan maupun laki-laki yang berkunjung cukup signifikan, namun di setiap bulannya dari bulan JanuariOktober 2016 mengalami fluktuasi tingkat kunjungan (Data Remaja Puskesmas Tanah Kalikedinding, 2016).

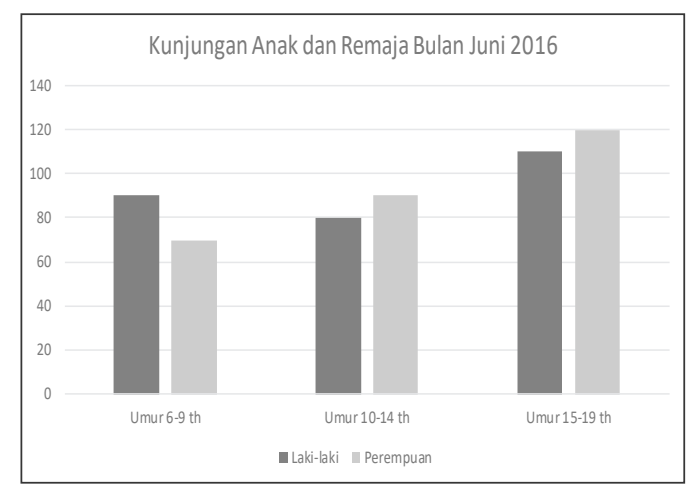

Gambar 1. Cakupan kunjungan anak dan remaja di Puskesmas Tanah Kalikedinding (Sumber: Data Puskesmas Tanah Kalikedinding) 


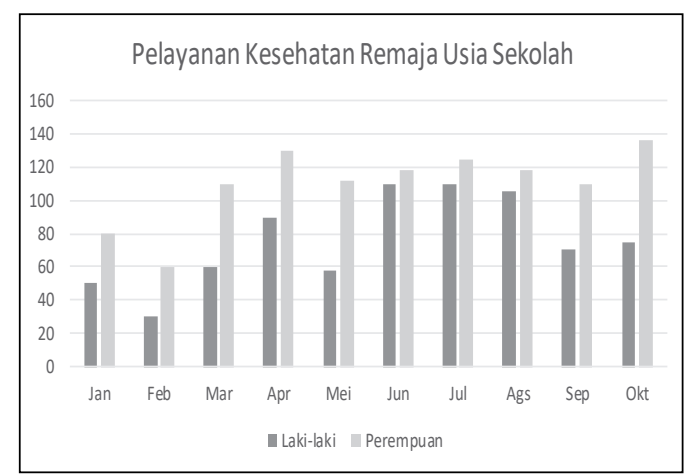

Gambar 2. Cakupan pelayanan kesehatan remaja usia sekolah tahun 2016 di Puskesmas Tanah Kalikedinding (Sumber: Data Puskesmas Tanah Kalikedinding)

Satu hal yang dianggap dapat mempengaruhi derajat kesehatan masyarakat di lingkungan sekitar ialah adanya pembentukan kader kesehatan (Sistiarani, 2013). Pemerintah memiliki upaya mewujudkan remaja sehat yaitu dengan terbentuknya Program Pelayanan Kesehatan Peduli Remaja (PKPR). Program ini dapat dilaksanakan di Puskesmas, Rumah Sakit atau sentra-sentra dimana remaja berkumpul seperti mall (Depkes, 2005). Dalam pelaksanaan PKPR di Puskesmas, remaja diberikan pelayanan khusus melalui perlakuan khusus yang disesuaikan dengan keinginan, selera dan kebutuhan remaja. Secara khusus, program PKPR bertujuan untuk meningkatkan penyediaan pelayanan kesehatan remaja yang berkualitas, meningkatkan pemanfaatan layanan Puskesmas oleh remaja untuk mendapatkan pelayanan kesehatan, meningkatkan pengetahuan dan keterampilan remaja dalam pencegahan masalah kesehatan dan meningkatkan keterlibatan remaja dalam upaya kesehatan dengan pembentukan kader.

Model pelayanan kesehatan remaja yang disebut dengan Pelayanan Kesehatan Peduli Remaja (PKPR) telah dikembangkan oleh Kementerian Kesehatan RI sejak tahun 2003. Pelayanan konseling dan peningkatan kemampuan remaja dalam menerapkan Pendidikan dan Keterampilan Hidup Sehat (PKHS) adalah beberapa ciri khas dari pelayanan kesehatan peduli remaja. Program ini lebih banyak bergerak dalam pemberian informasi tentang kesehatan remaja melalui wadah seperti Karang Taruna, Unit Kesehatan Sekolah (UKS), atau organisasi kader remaja yang dibentuk oleh Puskesmas. Pemberian pelayanan kesehatan remaja dilaksanakan sesuai keinginan dan kebutuhan remaja. (Depkes RI, 2014)

Puskesmas Tanah Kalikedinding telah memiliki kegiatan yang bersifat promotif dan preventif khususnya berkaitan dengan remaja. Upaya yang dilakukan Puskesmas adalah langkah untuk meningkatkan derajat kesehatan remaja di sekitar wilayah Tanah Kalikedinding. Kegiatan Pelayanan Kesehatan Peduli Remaja (PKPR) tentu didasarkan pada setiap kebutuhan dan keinginan dari remaja. PKPR di luar gedung meliputi kegiatan Upaya Kesehatan Sekolah (UKS), Rumah Remaja, dan Posyandu Remaja. Oleh karena itu, penulis tertarik untuk melakukan "Identifikasi Kebutuhan dan Harapan Kader Remaja Terhadap Program Kesehatan Remaja Di Puskesmas Tanah Kalikedinding Surabaya"

Program kesehatan remaja saat ini lebih banyak bergerak dalam pemberian informasi. Pemberian pelayanan khusus kepada remaja melalui perlakuan khusus yang disesuaikan dengan keinginan, selera, dan kebutuhan remaja belum dilaksanakan. Dengan demikian, remaja perlu dilibatkan secara aktif dalam perencanaan, pelaksanaan, dan penilaian pelayanan. Ide dan tindak nyata remaja akan lebih mengena dalam perencanaan dan pelaksanaan pelayanan karena mereka mengerti kebutuhan mereka. (Depkes RI, 2003) Oleh karena itu, penting halnya pada penelitian ini untuk mengetahui apa kebutuhan remaja saat ini terhadap program kesehatan remaja disesuaikan dengan program-program yang telah disediakan pemerintah.

\section{METODE}

Penelitian ini merupakan penelitian deskriptif dengan menggunakan pendekatan kualitatif. Penggalian data dilakukan dengan menggunakan metode in depth interview kepada sumber informan dengan pertanyaan seputar harapan dan kebutuhan 
remaja terhadap PKPR di Puskesmas Tanah Kalikedinding. Subjek penelitian terdiri dari peer educator Rumah Remaja, yaitu salah satu program inovasi Puskesmas Tanah Kalikedinding yang merujuk pada kesehatan reproduksi remaja, kader Posyandu Remaja, kader remaja di Pondok Pesantren Al-Fitroh dan kader UKS di SMAN 19 Surabaya. Jumlah informan yang digunakan pada penelitian ini adalah 6 orang kader kesehatan remaja yang pada setiap kategori subjek penelitian diwakilkan oleh 1 orang kader. Informan dipilih secara purposive, yaitu sesuai dengan karakteristik yang ditentukan oleh peneliti. Karakteristik yang dimaksud ialah remaja yang menjadi kader di wilayah Tanah Kalikedinding, berusia 15-24 tahun, dan dapat memberikan informasi kepada peneliti. Pengumpulan data diperoleh langsung dari lokasi penelitian dengan menggunakan teknik wawancara mendalam dan focus group discussion (FGD) yang dilakukan oleh peneliti dengan kader remaja terkait. Sedangkan pengolahan data penelitian dilakukan dengan prinsip berproses secara analisa deskriptif (content analysis).

\section{HASIL PENELITIAN}

Berdasarkan data hasil penelitian diketahui bahwa jumlah kader kesehatan remaja di wilayah Tanah Kalikedinding Surabaya yang menjadi informan penelitian ini adalah 6 orang.

Informan penelitian pada Tabel 1 . dikategorikan berdasarkan kelompok tatanan program kesehatan remaja yang berbeda yaitu dari Posyandu Remaja, UKS, Poskestren dan Rumah Remaja. Beberapa program yang telah disebutkan tersebut adalah program kesehatan remaja yang diaplikasikan di luar gedung Puskesmas Tanah Kalikedinding dan menjadi kegiatan UKM (Upaya Kesehatan Masyarakat) dengan sasaran remaja itu sendiri sebagai provider maupun user. Tabel 1 menunjukkan informan yang diwawancarai sebanyak 6 orang dengan sebagian besar berjenis kelamin perempuan (84\%), memiliki rentang umur antara 16-21 tahun, berpendidikan SMP-SMA, dan rata-rata posisi mereka memiliki kedudukan penting dalam setiap program, seperti menjadi penanggung jawab konseling, sekretaris, pengurus inti dan anggota aktif.

Penelitian ini menjadi kan kader remaja sebagai informan dikarenakan kader memiliki peranan penting di antara temantemannya yang lain yaitu sebagai peer yang dilatih untuk menangani masalah-masalah kesehatan perseorangan maupun kelompok (WHO, 1995). Apabila dihubungkan dengan tujuan penelitian ini ialah peran kader memiliki pengaruh dengan setiap jawaban yang ia berikan karena kader-kader tersebut mempunyai keterlibatan secara langsung dan memahami dengan benar setiap program kesehatan yang mereka lakukan.

Kader dipilih berdasarkan kondisi yang berbeda-beda. Kader Rumah Remaja dipilih berdasarkan keaktifan anggota dan lamanya ia menjadi anggota Rumah Remaja. Pemilihan tersebut juga bersifat sukarela. Berikut pernyataan dari ZN selaku penanggungjawab konseling Rumah Remaja yang keterlibatannya menjadi anggota sejak tahun 2011.

"Karena aku udah sejak lama sih disini, dari awal pembentukan Rumah Remaja tahun 2011 dulu, jadinya aku harus jadi salah satu peer buat teman-teman. Anggota-anggota lama itu diusahakan jadi kader karena mereka yang tahu betul mengenai Rumah Remaja" (ZN, 21 tahun)

Berbeda halnya dengan AZR, kader UKS SMAN 19 Surabaya, responden menyatakan bahwa kader UKS dipilih berdasarkan atas kesukarelaan siswa yang bersedia menjadi kader untuk mewakili setiap kelas mereka masing-masing. AZR mengaku bahwa tidak ada keterpaksaan dirinya untuk menjadi kader. Berikut pernyataan yang diungkapan AZR melalui kuotasi di bawah ini.

"Saya mengajukan sendiri sih mbak, soalnya kan saya juga anggota PMR jadi saya rasa saya cukup mampu memberikan edukasi ke teman-teman yang lain" (AZR, 17 tahun)

Sedangkan menurut LF (19 tahun) yang juga sebagai kader di Pos Kesehatan Pesantren Al-Fithrah, mengungkapkan bahwa menjadi kader adalah sebuah 
Tabel 1. Karakteristik Kader Remaja berdasarkan Kategori Informan, Umur, Jenis Kelamin, Pendidikan Terakhir dan Jabatan

\begin{tabular}{|c|c|c|c|c|}
\hline Kategori Informan & Umur & $\begin{array}{c}\text { Jenis } \\
\text { Kelamin }\end{array}$ & $\begin{array}{c}\text { Pendidikan } \\
\text { Terakhir }\end{array}$ & Jabatan \\
\hline Kader Rumah Remaja & 21 & $\mathrm{P}$ & SMA & $\begin{array}{l}\text { Penanggung Jawab } \\
\text { Konseling Rumah Remaja }\end{array}$ \\
\hline Kader Rumah Remaja & 20 & $\mathrm{P}$ & SMA & Sekretaris Rumah Remaja \\
\hline Kader UKS SMAN 19 Surabaya & 17 & $\mathrm{P}$ & SMP & Pengurus inti \\
\hline Kader UKS SMAN 19 Surabaya & 16 & $\mathrm{P}$ & SMP & Anggota \\
\hline Kader Posyandu Remaja & 19 & $\mathrm{~L}$ & SMA & Anggota aktif \\
\hline Kader Poskestren Al-Fitroh & 19 & $\mathrm{P}$ & SMP & Anggota aktif \\
\hline
\end{tabular}

Sumber: Data primer penelitian

keharusan apabila telah memasuki jenjang SMA di Pondok Pesantren, karena jenjang Pendidikan tersebut adalah jenjang yang paling tinggi, sehingga mampu memberikan edukasi yang cukup bagi teman-temannya yang lain.

"Saya udah SMA kelas IX mbak, jadiya sekalian jadikader juga disini. Soalnya yang paling tua. Selain itu saya juga menjadi ustadzah disini" (LF, 19 tahun)

Dari beberapa pernyataan LF dapat disimpulkan bahwa rekrutmen menjadi kader kesehatan remaja didasarkan pada keinginan kader informan sendiri dan tidak ada unsur keterpaksaan. Selain itu juga menjadi sebuah keharusan bagi mereka apabila mereka telah memasuki jenjang Pendidikan yang lebih tinggi dari anggota program kesehatan remaja yang lainnya.

Pusat pengembangan kesehatan masyarakat atau yang biasa dikenal dengan sebutan Puskesmas memilki peran memberikan pelayanan kesehatan secara menyeluruh dan terpadu kepada masyarakat di wilayah kerjanya dalam bentuk Upaya Keseheatan Berbasis Masyarakat (UKBM). Puskesmas Tanah Kalikedinding merupakan fasilitas kesehatan tingkat pertama di wilayah kelurahan Tanah Kalikedinding Kecamatan Kenjeran, Kota Surabaya. Berdasarkan data Profil Puskesmas Tanah Kalikedinding tahun 2017, jumlah penduduk yang berada di wilayah kerja Puskesmas tersebut adalah sebanyak 52.555 jiwa. Adapun dari jumlah tersebut sebanyak 9881 orang (18\%) adalah penduduk dalam usia remaja. Salah satu bentuk perhatian
Pemerintah terhadap remaja adalah dicanangkannya pembentukan PKPR tingkat Puskesmas tahun 2003. Prinsip dari PKPR adalah dapat terakses oleh semua golongan remaja, dapat diterima, layak, efektif, dan efisien.

Selama ini program Pelayanan Kesehatan Peduli Remaja (PKPR) telah dilaksanakan oleh Puskesmas Tanah Kalikedinding Surabaya dimana penyelenggaraannya disesuaikan dengan situasi dan kondisi di wilayah kerja tersebut. Pengembangan standar yang dapat menjamin mutu PKPR diterapkan secara terukur, merata, dan ajeg. Proses pengembangan standar ini dilakukan melalui beberapa langkah yang dibutuhkan sesuai dengan Standar Nasional PKPR. Standar Nasional PKPR adalah dokumen tertulis yang berisi berbagai persyaratan mutu PKPR, yang meliputi persyaratan mutu masukan (input), proses, maupun luaran (output). Standar Nasional PKPR dikembangkan untuk digunakan sebagai pedoman dalam mengarahkan dan menilai mutu PKPR. Jadi pada dasarnya Standar Nasional PKPR adalah pedoman pengendalian mutu yang digunakan oleh fasilitas kesehatan untuk meningkatkan dan menjamin mutu PKPR yang telah dilaksanakan. Untuk dapat menggunakan standar ini, pertama-tama fasilitas kesehatan harus terlebih dahulu mampu melaksanakan PKPR. PKPR menjadi salah satu program unggulan di Puskesmas Tanah Kalikedinding, sebab program ini memiliki banyak tugas pokok dan fungsi (tupoksi) kegiatan yang dilaksanakan. PKPR di Puskesmas tersebut telah menjalankan 
kegiatannya sesuai dengan Standar Nasional PKPR yang dikeluarkan oleh Kementerian Kesehatan Republik Indonesia (Kemenkes RI) sebagai pedoman. Hal ini dibuktikan dengan adanya pelayanan di dalam gedung dan di luar gedung. Pelayanan dalam gedung lebih ditekankan pada Upaya Pelayanan Perorangan (UKP) yaitu dengan konseling di Poli Psikologi dan pemeriksaan kesehatan secara medis.

Sedangkan Upaya Kesehatan Masyarakat (UKM) pada PKPR di Puskesmas Tanah Kalikedinding dilakukan di luar gedung. Kegiatan-kegiatan tersebut antara lain UKS, Posyandu Remaja, dan Rumah Remaja. Pada implementasinya, ketiga kegiatan tersebut dilaksanakan rutin. Upaya Kesehatan Sekolah (UKS) mempunyai petugas khusus dan memiliki jadwal rutin. Sasaran dari UKS yaitu Sekolah Dasar (SD), Sekolah Menengah Pertama (SMP), dan Sekolah Menengah Atas (SMA) di wilayah binaan Puskesmas Tanah Kalikedinding. Puskesmas memiliki 2 UKS binaan di SMPN 15 Surabaya dan di SMAN 19 Surabaya. Sekolah tersebut mendapatkan predikat UKS terbaik dan UKS percontohan di wilayah Kelurahan Tanah Kalikedinding dan Kecamatan Kenjeran. Hal ini menjadi prestasi yang baik bagi pemerintah daerah setempat khususnya UPTD Puskesmas Tanah Kalikedinding.

Selain itu, terdapat kegiatan PKPR lainnya di luar gedung yang termasuk dalam Upaya Kesehatan Berbasis Masyarakat (UKBM) yaitu posyandu remaja dan Rumah Remaja. Pada implementasinya, dua kegiatan ini saling memiliki keterkaitan. Kegiatan tersebut memiliki sasaran remaja umum di wilayah Tanah Kalikedinding. Namun, dari hasil wawancara kepada petugas dan observasi, baik kegiatan posyandu remaja dan Rumah Remaja belum berjalan optimal. Banyak faktor determinan yang menjadi penghambat kegiatan-kegiatan ini, seperti Sumber Daya Manusia (SDM) yang kurang dari sisi petugas dikarenakan petugas hanya satu orang. Selain itu SDM dari sasaran cukup sulit dipertemukan, jadwal pelaksanaan kegiatan yang tidak pasti, anggaran dana kegiatan minim, dan banyak faktor lainnya. Hal ini menjadi bahan evaluasi yang harus diperhatikan mengingat bahwa seharusnya kegiatan promosi kesehatan dan pelayanan kesehatan tidak harus dilakukan di dalam gedung saja, melainkan di luar gedung juga, Karena masih banyak sasaran remaja di luar yang perlu mendapatkan Komunikasi, Informasi, dan Edukasi (KIE) serta intervensi.

Kader-kader remaja pada setiap program PKPR ini dapat dikategorikan menjadi kelompok user dan provider. Mereka adalah pengguna sekaligus pemberi pelayanan untuk teman-teman sebayanya. Kader memiliki peran dan pengaruh penting dalam meningkatkan kesehatan remaja. Program PKPR di Tanah Kalikedinding sudah tersedia sejak lama dan sudah dimanfaatkan oleh remaja-remaja di sekitar. Seiring dengan berjalannya waktu perlu adanya evaluasi mengenai program PKPR di Puskesmas Tanah Kalikedinding. Evaluasi dapat dilihat melalui bagaimana pelaksanaan program itu sendiri dan hal yang paling penting ialah apa yang menjadi kebutuhan dan harapan remaja terhadap program PKPR.

Upaya Kesehatan Sekolah (UKS) adalah salah satu program PKPR di tingkat pendidikan formal dengan sasaran remaja usia sekolah. Berdasarkan hasil wawancara dengan kader UKS di SMAN 19 Surabaya diketahui bahwa apa yang mereka butuhkan saat ini terhadap kegiatan UKS selain pemeriksaan kesehatan rutin ialah adanya penyuluhan kesehatan yang bertemakan reproduksi remaja. Ia juga berpendapat bahwa kesehatan reproduksi sudah -bukan hal yang tabu bagi remaja se-usia mereka bahkan mereka wajib mengetahuinya agar dapat menjadi bekal pengetahuan dikedepannya.

Selain itu pendapat berbeda diutarakan oleh salah satu kader UKS yang menyatakan bahwa para kader-kader ini adalah garda utama untuk meningkatkan pengetahuan dan kesadaran teman-teman sebayanya. Oleh karena itu mereka menginginkan adanya pembinaan kader yang rutin, diberikan materi-materi mengenai kesehatan remaja agar mereka dapat dengan mudah memberikan edukasi kepada teman sebayanya. Secara tersirat kader menginginkan dibentuknya konselor sebaya yang berfungsi melakukan konseling untuk 
teman sebayanya yang lain. Pelaksanaan konseling bersama teman dapat membuat remaja menjadi semakin terbuka terhadap kesehatannya. Pernyataan diatas dapat ditunjukkan dari hasil wawancara berikut ini:

"Selain pemeriksaan kesehatan seharusnya juga diberikan penyuluhan tentang kesehatan khususnya kesehatan remaja jadi ada bekal tambahan buat remaja sekolah" (LS. 16 tahun)

"Mungkin lebih ditingkatkan lagi pembinaan buat kader UKS nya, kalau perlu ada wadah buat konseling sesama teman" (AZR, 17 tahun)

Kebutuhan dan harapan remaja pos kesehatan pesantren (poskestren) serupa juga diutarakan melalui salah satu kader poskestren bahwa mereka menginginkan adanya pembentukan dan pembinaan konselor sebaya supaya bisa menjadi peer educator dan membantu memecahkan permasalahan bagi teman-temannya. Berikut kuotasi wawancara dengan kader poskestren Al-Fitroh.

"Kalau disini (poskestren) penyuluhan sudah sering sih, kadang dari puskesmas kadang dari luar juga. Mungkin lebih ke pendekatan secara personal aja, biar kalau ada yang curhat bisa enak" (LF, 19 tahun)

Puskesmas Tanah Kalikedinding Surabaya memiliki UKS binaan yang terdapat di SMAN 19 Surabaya dan di SMPN 15 Surabaya. Hanya 2 institusi pendidikan tersebut yang selama ini menjadi fokus utama kegiatan UKS di Tanah Kalikedinding, Karena telah memiliki banyak prestasi seperti pernah menjuarai perlombaan UKS Teladan dan Percontohan se-Kota Surabaya. Namun di sisi lain, masih banyak sekolah-sekolah di wilayah tersebut yang juga ingin mendapatkan perhatian lebih terhadap UKSnya. Dan bukan hanya UKS yang memang sudah menjadi unggulan saja. Karena sekolah-sekolah yang belum terjamah Pendidikan kesehatannya masih sangat membutuhkan pembinaan lebih guna meningkatkan derajat kesehatan siswa dan warga sekolahnya.

Posyandu remaja adalah program kesehatan untuk remaja yang dilaksanakan di setiap RW di Kelurahan Tanah Kalikedinding dengan melibatkan remaja karang taruna dan remaja di sekitarnya. Salah satu kader posyandu remaja berpendapat bahwa sebaiknya kegiatan posyandu remaja ada jadwal rutin dan khusus supaya remaja dapat menyesuaikan dengan kegiatan mereka masing-masing sehingga dengan begitu kehadiran remaja menjadi banyak.

Inovasi dari kegiatan yang monoton juga sangat dibutuhkan oleh remaja. Remaja menginginkan ada kegiatan baru yang kreatif yang dapat menarik minat dari remaja setempat. Apabila sebelumnya kegiatan hanya berfokus pada kegiatan yang bersifat kuratif seperti pemeriksaan kesehatan, maka remaja juga menginginkan kegiatan yang bersifat promotive dan preventif, seperti penyuluhan kesehatan remaja, edukasi dengan cara yang seru, sharing bersama mengenai permasalahan remaja saat ini, dan lain sebagainya. Walaupun hanya seminar dan penyuluhan, Hal ini dibuktikan dengan cuplikan wawancara bersama kader posyandu remaja sebagai berikut.
"Kalau bisa ada jadwal rutin biar anak-anak bisa menyesuaikan dengan kegiatan masing-masing, jadi banyak yang datang" (SYF, 19 tahun)

"Ada kegiatan yang baru dan nggak itu itu aja" (SYF, 19 tahun)

Berdasarkan hasil wawancara bersama kader Rumah Remaja, didapatkan pernyataan melalui kuotasi sebagai berikut.

"Saya rasanya sih dari kita itu kurang diperencanaannya. Karena kadang tidak ada time line yang jelas" (ZN, 21 tahun)

"Harapannya $R R$ jadi banyak anggotanya, nggak anak-anak itu aja, kegiatannya lebih inovatif, dan lebih sering melakukan sosialisasi biar nggak dibilang vacuum" (ID, 20 tahun)

Rumah Remaja adalah salah satu program inovasi dari Puskesmas yang berdiri sejak tahun 2011. Program ini muncul karena adanya kebutuhan dari remaja sekitar Tanah Kalikedinding yang membutuhkan wadah untuk mengaspirasikan kegiatan mereka menuju arah positif. Pernyataan 
hasil wawancara diatas dapat disimpulkan bahwa menurut mereka Rumah Remaja masih belum matang dalam hal perencanaan kegiatan. Timeline yang dibuat pun masih tidak jelas. Sehingga hal tersebut berdampak pada kegiatan yang akan mereka lakukan.

Harapan lain juga disampaikan kader Rumah Remaja mengenai kegiatan yang inovatif. Keinginan mereka adalah adanya kegiatan baru di setiap tahun, yang tidak sekedar meniru dan mengulang kegiatan di tahun sebelumnya, sehingga dapat menarik remaja lain untuk bergabung. Selain itu, Rumah Remaja juga perlu adanya sosialisasi ke publik secara rutin, baik sosialisasi mengenai Rumah Remaja hingga melakukan penyuluhan dan edukasi ke remaja di luar Rumah Remaja. Hal tersebut bermaksud agar Rumah Remaja tidak terkesan vacuum.

Keterlibatan remaja adalah salah satu kriteria PKPR (Depkes RI, 2003). Kelompok ini merupakan pihak yang diharapkan mendapatkan manfaat atau hasil positif terhadap implementasi program PKPR di Puskesmas Tanah Kalikedinding Surabaya. Adanya peer atau biasa disebut sebagai kader juga menjadi pengaruh terhadap kesehatan remaja. Kader kesehatan remaja ialah beberapa remaja yang ditunjuk sebagai perwakilan dari remaja lainnya guna ikut melaksanakan sebagian pelayanan kesehatan terhadap diri sendiri, keluarga, teman sebaya pada khususnya dan lingkungan pada umumnya (Undang-Undang Nomor 23 Tahun 1992). Kader kesehatan remaja memiliki pengetahuan tentang kesehatan remaja yang mau membantu bersama-sama memecahkan masalah kesehatan remaja sebayanya.

Kader remaja pada setiap program PKPR Puskesmas Tanah Kalikedinding memiliki peran dan fungsi masingmasing. Keikutsertaan mereka menjadi kader dapat dilihat dari tujuan awal dan kebutuhan mereka. Menurut McClelland (2003), terdapat tiga jenis kebutuhan dalam diri manusia terhadap suatu hal, yaitu kebutuhan akan prestasi, kekuasaan, dan kelompok pertemanan. Berdasarkan dari hasil wawancara, keterlibatan kader remaja dari berbagai program ialah mereka membutuhkan wadah untuk mengembangkan diri, menjadi peer bagi teman-teman sebayanya, dan ingin berprestasi terhadap apa yang mereka lakukan. Dorongan ini disebut kebutuhan akan prestasi. Orang-orang dengan prestasi tinggi cenderung mencari situasi-situasi dimana dapat memperoleh tanggung jawab pribadi untuk menemukan berbagai penyelesaian problem. Tidak ada unsur keterpaksaan dalam keterlibatan kader, mereka murni atas dasar kemauan mereka sendiri. Selain itu, keinginan mereka untuk memiliki hubungan-hubungan persahabatan kepada teman sebayanya secara dekat yang menjadi kebutuhan kader remaja.

Berbeda halnya dengan kader Rumah Remaja, selain atas dasar sukarela, menjadi kader adalah sebuah kewajiban dan keutamaan bagi remaja yang memiliki frekuensi keikutsertaan yang cukup lama diprogram kesehatan tersebut. Sehingga remaja tersebut memiliki cukup wewenang dan pengalaman untuk menjadi kader bagi teman-teman sebayanya. Hal tersebut dengan adanya keinginan untuk memiliki dampak, pengaruh, dan kontrol terhadap orang-orang lain. Orang-orang dengan kebutuhan akan kekuasaan yang tinggi selalu menikmati tugas-tugas untuk mempengaruhi orangorang lain, lebih menyukai ditempatkan dalam situasi kompetitif, berorientasi status, dan cenderung lebih memperhatikan prestise dan pengaruh terhadap orang-orang lain daripada hasil kerja yang efektif (Mc Clelland, 2003).

Analisis Kebutuhan Remaja terhadap Program Kesehatan Remaja di Puskesmas Tanah Kalikedinding Surabaya.

Di Indonesia, Puskesmas merupakan unit penanggungjawab penyelenggaraan upaya kesehatan masyarakat untuk jenjang tingkat pertama. Pada saat ini puskesmas telah didirikan di hampir seluruh pelosok tanah air. Berdasarkan Keputusan Menteri Kesehatan Tahun 2004, disebutkan bahwa Puskesmas memiliki fungsi diantaranya sebagai pusat pemberdayaan masyarakat, pusat penggerak pembangunan berwawasan kesehatan, dan pusat pelayanan kesehatan strata pertama baik seorangan maupun masyarakat.

Kepemilikan peran pada Puskesmas menjadi hal yang strategis sebagai upaya 
peningkatan taraf kesehatan masyarakat dengan fungsi memberikan pelayanan kesehatan terdepan, termasuk untuk remaja. Permasalahan yang dihadapi remaja saat ini semakin berkembang luas, sehingga memerlukan perhatian lebih. Salah satu program yang dicanangkan oleh pemerintah adalah dengan pembentukan program Pelayanan Kesehatan Peduli Remaja (PKPR). Pelayanan Kesehatan Peduli Remaja (PKPR) merupakan pelayanan kesehatan yang ditujukan dan dapat dijangkau oleh remaja, menyenangkan, menerima remaja dengan tangan terbuka, menghargai remaja, menjaga kerahasiaan, peka akan kebutuhan terkait dengan kesehatannya serta efektif dan efisien dalam memenuhi kebutuhan tersebut (DepKes RI, 2005). Dengan semakin banyaknya permasalahan yang dihadapi remaja, program ini seharusnya menjadi prioritas utama dalam pengembangan program kerja Puskesmas.

Hasil menunjukkan bahwa selama ini bentuk kegiatan yang dilakukan oleh Puskesmas Tanah Kalikedinding terkait pelayanan Kesehatan Reproduksi Remaja (KRR) dalam PKPR sudah sesuai dengan pedoman Depkes RI tentang pelayanan kesehatan remaja. Telah dilakukan pula pengembangan program inovasi dibuktikan dengan adanya program Rumah Remaja sejak tahun 2011. Dengan demikian Puskesmas sudah melakukan pengembangan untuk kegiatan atau inovasi untuk meningkatkan cakupan pelayanan KRR.

Respons remaja terhadap pelayanan Kesehatan Reproduksi Remaja (KRR) yang diselenggarakan Puskesmas Tanah Kalikedinding cukup tinggi. Hal ini dibuktikan dengan angka keterlibatan remaja yang tinggi pada setiap program PKPR yang diselenggarakan oleh Puskesmas. Namun masih besar harapan dan keinginan remaja, yang dalam hal ini diwakili oleh kader, terhadap kegiatan-kegiatan yang berkaitan dengan program PKPR, yaitu UKS, Poskestren, Posyandu Remaja, dan Rumah Remaja. Kebutuhan remaja akan layanan kesehatan reproduksi akan berbanding lurus dengan kesiapan para provider. (Widjanarko, 1999) Bagi remaja provider, ini amatlah penting. Provider yang dimaksud adalah pemberi pelayanan kesehatan baik instansi maupun Sumber Daya Manusia (SDM) nya. Dengan adanya kebutuhan dan harapan remaja yang telah diulas pada hasil penelitian, maka dapat dikatakan bahwa remaja sebagian besar menginginkan provider haruslah dapat menjawab persoalan remaja, dan itu bisa dilakukan apabila provider juga dekat dengan remaja. Kader kesehatan remaja adalah jawaban sementara dari harapan mereka, karena kader remaja ialah orang yang tidak terlalu jauh usianya dari remaja sehingga persoalan yang ada bisa didekati secara empati.

Kebutuhan remaja mengenai program kesehatan remaja ialah mereka menginginkan adanya kegiatan yang inovatif, kreatif, tidak monoton dan selalu baru. Supaya dapat menarik perhatian remaja untuk terus meningkatkan derajat kesehatan mereka. Selain itu, kegiatan yang dilakukan juga tidak hanya seputar kegiatan medis atau cenderung bersifat kuratif. Menurut WHO, pengertian kesehatan secara luas tidak hanya meliputi namun juga meliputi aspek mental dan sosial. Remaja menginginkan adanya peningkatan kegiatan yang bersifat promotive dan preventif. Kegiatan yang seperti itu dapat dilakukan dengan penyuluhan, sosialisasi, pemberian edukasi atau Pendidikan. Pendidikan kesehatan merupakan segala suatu upaya yang direncanakan untuk mempengaruhi orang lain, baik individu, kelompok, atau masyarakat, sehinga mereka melakukan apa yang diharapkan untuk memelihara dan meningkatkan kesehatan yang kondusif dari promosi kesehatan (Notoadmojo, 2012). Maka daripada itu, besar harapan dan keinginan para remaja terhadap kegiatan PKPR ini untuk meningkatkan derajat kesehatan remaja.

\section{KESIMPULAN}

Keterlibatan remaja menjadi hal yang penting dalam kesehatan remaja. Kelompok ini merupakan pihak yang diharapkan mendapatkan manfaat atau hasil positif terhadap implementasi program PKPR di Puskesmas Tanah Kalikedinding Surabaya. Adanya peer atau biasa disebut sebagai kader juga menjadi pengaruh terhadap 
kesehatan remaja. Program PKPR di Puskesmas sudah ada sejak tahun 2003 dan telah diterapkan di Tanah Kalikedinding dengan sasaran utama ialah remaja sekitar. Walaupun telah lama diterapkan, namun remaja sebagai pengguna pelayanan memiliki harapan dan kebutuhan terhadap program tersebut.

Kader remaja di wilayah Tanah Kalikedinding menginginkan ada inovasi kegiatan di setiap tahunnya, yaitu berupa tema yang selalu up to date yang disesuaikan dengan permasalahan kesehatan remaja saat ini. Hal tersebut diharapkan agar remaja tidak bosan dengan kegiatan yang sifatnya monoton. Selain itu, kegiatan yang diimplementasikan juga harus bersifat preventif dan promotif. Kegiatan preventif dan promotif dapat diaplikasikan melalui penyuluhan kesehatan yang dikemas dengan berbagai games, sosialisasi dari remaja untuk remaja dan oleh remaja itu sendiri, serta edukasi seputar KRR dengan melibatkan fasilitator yang komunikatif. Oleh karena itu, sudah selayaknya Puskesmas Tanah Kalikedinding selaku fasilitas kesehatan masyarakat pada wilayah tersebut meningkatkan program PKPR sesuai kebutuhan dan harapan dari remaja sekitar.

\section{DAFTAR PUSTAKA}

Undang-Undang Nomor 23 Tahun 1992 tentang Kesehatan Pasal 17.

Muthmainnah. 2013. Analisis Stakeholder Remaja terhadap Implementasi PKPR di Kota Semarang. Jurnal Promkes vol.1 no.2 Desember 2013: 170-183.

BKKBN. 2010. "Pendataan Perilaku Remaja dan Aktivitas Saat Berpacaran.".

BPS. 2010. "Sensus Penduduk Indonesia 2010.".

Notoadmojo, S. 2012. Promosi Kesehatan dan Ilmu Perilaku. Jakarta: Rineke Cipta.

Maleong, L.J. 2004. Metodologi Penelitian Kualitatif. Bandung: Remaja Rosdakarya, hal. 3.
Listyaningrum, R. 2008. Perencanaan Promosi Kesehatan. Terdapat di dretno listyaningrum.staff.gunadarma.ac.id/.../6_ PERE [diakses 3 Januari 2017].

Dinas Kesehatan Kota Surabaya. 2015. "Profil Kesehatan Kota Surabaya Tahun 2015".

Departemen Kesehatan RI. 2003. Materi Pelatihan Pelayanan Kesehatan Peduli remaja. Jakarta.

Anonim. Pusat Informasi dan konseling Kesehatan Reproduksi Remaja (PIKKRR) diakses pada 26 Desember 2016 pada situs https://www.k4health.org/ sites/default/files/Bagian_II_Program Pemerintah_PIK-KRR.pdf.

Badan Pusat Statistik, Hasil Sensus Penduduk tahun 2010.

Badan Pusat Statistik (BPS), BKKBN, Departemen Kesehatan dan Macro Internasional; Survei Kesehatan Reproduksi Remaja tahun 2007, Jakarta.

Badan Pusat Statistik (BPS) dan ORC Macro. 2003. Survei Demografi dan Kesehatan Indonesia 2007. Calverton, Maryland, USA: BPS and ORC Macro

BKKBN. 2006. Komunikasi, Informasi dan Edukasi Kesehatan Reproduksi Remaja: Jakarta.

BKKBN. 2012. Ada Apa dengan Remaja. In: brief, P (ed.) KAJIAN PROFIL PENDUDUK REMAJA (10-24 THN). Jakarta.

Depkes RI. 2014. Pedoman Pelayanan Kesehatan Peduli Remaja. Jakarta.

Farida, N. 2011. Thesis Rumah Remaja sebagai Model Model Pemberdayaan Kesehatan Reproduksi Remaja: Universitas Airlangga Surabaya.

Farida, N., 2011. Rumah Remaja sebagai Model Model Pemberdayaan Kesehatan Reproduksi Remaja. Jurnal Promkes, Vol. 1, No. 2 Desember 2014: 153-162.

Puskesmas Tanah Kalikedinding. 2016. Data Distribusi Pelayanan Kesehatan pada Remaja. Surabaya.

McClelland, D.C. (1987). Human Motivation. New York: Cambridge University Press. 
Arsani, N.L.K, dkk. 2013. Peranan Program PKPR (Pelayanan Kesehatan Peduli Remaja) terhadap Kesehatan Reproduksi Remaja di Kecamatan Buleleng, Jurnal Ilmu Sosial dan Humaniora. Vol.2. No.1 April 2013 ISSN: 2303-298.

Sari, Utami, S. 2015. Pengaruh Peer Education terhadap Perilaku Personal Hygiene Genetalia dalam Pencegahan Kanker Serviks pada Remaja Putri di SMP
Negeri 10 Denpasar [WWW Document]. URL ojs.unud.ac.id/index.php/coping/ article/download/10811/12681 (accessed 4.30.15).

Friskarin, K., dan Manalu, H.S.P. 2016. Implementasi Program Pelayanan Kesehatan Peduli Remaja (PKPR) di Tingkat Puskesmas DKI Jakarta. Jurnal Ekologi Kesehatan Vol. 15 No. 1, Juni 2016: 66-75. 